\title{
EFFECT OF ELEVATED TEMPERATURE ON RESIDUAL STRENGTH OF SELF COMPACTED CONCRETE
}

\author{
Snahashish Paul ${ }^{1}$, Muhammad Harunur Rashid ${ }^{1}$, and Md. Anisur Rahman ${ }^{2}$ \\ ${ }^{1}$ Department of Civil Engineering, Khulna University of Engineering \& Technology, Khulna - 9203 \\ ${ }^{2}$ Deputy Project Director, Dhaka Khulna (N-8) Project, Bangladesh
}

Received: 20 September 2020

Accepted: 03 December 2020

\begin{abstract}
Self Compacted Concrete (SCC) is a material used in the construction industry to ensure proper compaction of concrete without providing any external energy. In case of exposure of SCC to accidental fire, an assessment of its residual capacity is needed. This study covers the observation of residual compressive strength, tensile strength and modulus of elasticity of self compacted concrete under elevated temperatures (150, 300, 450, 600 and $800^{\circ} \mathrm{C}$ ) and cooling conditions (air cooling and water quenching). The compressive strength increased at $150^{\circ} \mathrm{C}$ and decreased continuously after this temperature. However, tensile strength and modulus of elasticity decreased at elevated temperatures compared with ambient temperature. The compressive strength at ambient temperature $\left(30^{\circ} \mathrm{C}\right)$ was $27.0 \mathrm{MPa}$, and it raised to $28.7 \mathrm{MPa}$ at $150^{\circ} \mathrm{C}$ for air cooling and $27.8 \mathrm{MPa}$ for water quenching.
\end{abstract}

Keywords: Cooling Condition; Elevated Temperature; Mechanical Properties; Rheological Properties; Self Compacted Concrete.

\section{INTRODUCTION}

Self-Compacted concrete is characterized as a high-performance concrete that has excellent fresh-state deformability and high segregation resistance and can be put and compacted under its own weight without any external energy being applied. It was first introduced in Japan in 1988 and was named as "High-Performance Concrete", and further development was carried out by different researchers (Bartos \& Grauers, 1999; Okamura $\&$ Ouchi, 2003). Self-compacted concrete is a better option than normal concrete in areas where compaction and placement of concrete are difficult (Mathew \& Paul, 2012). SCC occupies the shape of a formwork in plastic state and when hardened it creates a dense and homogenous concrete with better engineering properties and is more durable than traditional vibrated concrete (Lenka \& Panda, 2017; Salhi et al., 2017). However, While the use of SCC is technologically, socially and overall beneficial, its production may cost between 2-3 times higher than normal concrete. Hence for the reduction of the cost of SCC, mineral admixtures could be used to increase the workability of the concrete mix (Heikal et al., 2013; Pathak \& Siddique, 2012). The composition of SCC can fluctuate between plants and countries alike, even if the fresh and hardened properties are similar, in terms of flowing and passing capability. Concrete interfaces zone properties probably improved due to the presence of higher amount of fine and extra-fine particles (Ding et al., 2010; 2011). SCC has the ability to flow without any induced compaction through any congested sections between the reinforcement and fills entirely within the formworks without leaving any voids (Badogiannis et al., 2015; Calado et al., 2015; Kanadasan et al., 2015; Rama Seshu \& Pratusha, 2013).

Now-a-days fire accident has become one of the most frequently occurring hazards all over the worlds. Several fire accidents due to the various reasons and with different magnitudes are frequently happening. So, there is a growing concern about the structural safety before construction of an infrastructure and reconstruction after a building has experienced a fire hazard. In cases of an accidental explosion, concrete properties change after burning. Hence, the change in concrete properties due to extreme temperature exposures is necessary to understand (Vasusmitha \& Rao, 2012). A large number of studies were performed on normal strength concrete and high strength concrete on residual strength after facing high temperature (Anand et al., 2014; Castillo, 1990; Phan \& Carino, 1998; Rama Seshu \& Pratusha, 2013). Spalling and reduction in strength due to high temperature lead the concrete to failure. The type of powder used in the production of SCC will significantly impact the spalling and strength characteristics (Bakhtiyari et al., 2011). The study on the properties of SCC exposed to elevated temperatures is a growing concern now-a-days (Noumowé et al., 2006). Some investigations were performed on residual compressive strength of SCC exposed to high temperature (Annerel et al., 2007; Fares et al., 2009, 2010; Heikal et al., 2013; Persson, 2004; Tufail et al., 2017). The strength of concrete decreased while heated to elevated temperatures of $650^{\circ} \mathrm{C}$ and thereafter (Demirel \& Keleştemur, 2010; Tufail et al., 2017). It was observed that the strength loss between $100-200^{\circ} \mathrm{C}$ (Chang et al., 2006), 100-400 ${ }^{\circ} \mathrm{C}$ is slightly lower compared to the strength loss after these temperatures (Anand \& Arulraj, 2014; Tao et al., 2010). Some researchers investigated on the performance of elevated temperature of concrete and found that concrete temperature increases up-to $200^{\circ} \mathrm{C}$ (Heikal, 2000), $300^{\circ} \mathrm{C}$ (Fares et al., 2009; Rama Seshu \& Pratusha, 2013) 
and after these temperatures, concrete strength started to decrease. However, this variation of strength loss is different for different grade of concrete. High strength concrete is more sensitive to temperature than normal strength concrete. Higher grade of concrete shows a significant reduction in strength and stiffness than normal strength concrete (Anand \& Arulraj, 2014; Tao et al., 2010). In case of normal strength concrete, SCC is more sensitive to temperature than normally vibrated concrete (Rama Seshu \& Pratusha, 2013). Some experimental research on the performance of SCC was carried out using different mineral additives and elevated to high temperature of up to $600^{\circ} \mathrm{C}$ (Rukavina et al., 2015). It was found that mineral additives have great influence on the residual compressive strength between ambient temperature and $400^{\circ} \mathrm{C}$.

At the time of exposure of reinforced concrete structural elements to high temperature due to good fire resistance properties of concrete, it is often possible for the structure to withstand. But at the same time, the chemical composition, physical structure and water content of concrete are modified. Cooling conditions play an important role in these modifications and greatly produce an impact on the strength characteristics of concrete. So, it is necessary to observe the mechanical properties of concrete after a fire accident when extinguishing fire by water or goes out slowly (Rama Seshu \& Pratusha, 2013).

In this study, investigations on the residual capacity of concrete such as residual compression capacity, residual tension capacity modulus of elasticity will be done due to exposure of self-compacting concrete to elevated temperature and two different cooling conditions for evaluating the structural performance.

\section{MATERIALS AND METHODS}

\subsection{Materials}

In this experiment, for preparing self compacted concrete locally available materials were used. Ordinary Portland cement (CEM-I) was used as a binding agent with coarse sand and crushed stone. To fill the void of the concrete stone dust was used as a filler material and for getting higher slump value with moderate w/c ratio, superplasticizer was used. The properties of the materials and the gradation curve for coarse aggregate used in this research are represented in Table 1 \& Figure 1, respectively.

Table 1: Properties of materials used to prepare SCC

\begin{tabular}{|c|c|c|c|c|}
\hline Materials & Properties & Unit & value & Test Standard \\
\hline \multirow{4}{*}{$\begin{array}{l}\text { Binder } \\
\text { Cement) }\end{array}$} & Specific gravity & - & 3.15 & ASTM C128 \\
\hline & Normal Consistency & $\%$ & 26.5 & ASTM C187 \\
\hline & Initial Setting Time & Minutes & 155 & ASTM C191 \\
\hline & Final Setting Time & Minutes & 275 & ASTM C191 \\
\hline \multirow{4}{*}{ Fine aggregate } & Specific gravity (SSD) & - & 2.55 & ASTM C128 \\
\hline & Absorption & $\%$ & 4.55 & ASTM C128 \\
\hline & Fineness modulus & - & 2.70 & ASTM C136 \\
\hline & Unit weight & $\mathrm{Kg} / \mathrm{m}^{3}$ & 1573 & ASTM C29 \\
\hline Filler (Stone Dust) & Specific gravity & - & 2.78 & ASTM C 128 \\
\hline \multirow{4}{*}{$\begin{array}{l}\text { Coarse aggregate } \\
\text { (Maximum Size of } \\
\text { aggregate }=1 / 2 \text { inch) }\end{array}$} & Specific gravity (SSD) & - & 2.78 & ASTM C127 \\
\hline & Absorption & $\%$ & 1.93 & ASTM C127 \\
\hline & Void & $\%$ & 42.7 & ASTM C29 \\
\hline & Unit weight & $\mathrm{Kg} / \mathrm{m}^{3}$ & 1587 & ASTM C29 \\
\hline
\end{tabular}

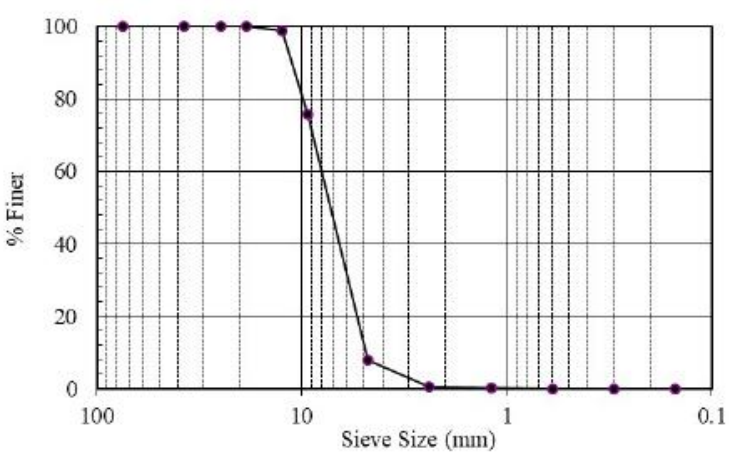

Figure 1: Gradation curve for coarse aggregate 


\subsection{Mix Design for Self Compacted Concrete}

The first aim of this mix design is to find out the optimum proportions of aggregate that can produce a highly compacted concrete when filling a casing by the self-weight of that concrete. The calculation was done by using the physical properties of the aggregate used to achieve theoretically almost zero void condition. Theoretical zero void condition was achieved by determining the voids between the aggregates and filling that voids by cement paste as well as filler paste. To ensure proper flowing ability, passing ability and resistance to segregation ability of the concrete several trials were done and a final mix proportion was obtained that satisfy all the requirements of self-compacted concrete. The trials were done by adjusting the water cement ratio and the dose of superplasticizer. Table 2 represents the final mix proportions of self-compacted concrete.

Table 2: Final Mix proportions of SCC

\begin{tabular}{ll}
\hline Materials & Amount \\
\hline Cement (CEM-I) & $485 \mathrm{~kg} / \mathrm{m}^{3}$ \\
Coarse aggregate (Stone Chips) & $713.35 \mathrm{~kg} / \mathrm{m}^{3}$ \\
Fine aggregate (Coarse Sand) & $865.94 \mathrm{~kg} / \mathrm{m}^{3}$ \\
Water & $237 \mathrm{~kg} / \mathrm{m}^{3}$ \\
Filler Material (Stone dust) & $17.85 \mathrm{~kg} / \mathrm{m}^{3}$ \\
Super plasticizer (Con-lub) & $12 \mathrm{~mL} / \mathrm{kg}$ of cement \\
Water cement ratio, W/C & 0.474 \\
Water filer ratio, W/F & 0.40 \\
\hline
\end{tabular}

\subsection{Test on Fresh Properties of Self-Compacted Concrete}

The essential properties on which concrete is claimed as self-compacted concrete (SCC) can be found by some tests on the fresh state of that concrete. Slump flow test was done to ensure the flowing ability, V funnel flow tests at $10 \mathrm{~s}$, and $5 \mathrm{~min}\left(\mathrm{~T}_{5 \mathrm{~min}}\right)$ was done to check the flowing ability as well as resistance to segregation ability and $\mathrm{L}$ box test was conducted to assure the passing ability of concrete through congested openings like beamcolumn joint. All properties were determined in 30 minutes following mixing in order to maintain their fresh quality and to reduce the impact of workability loss on the test results.
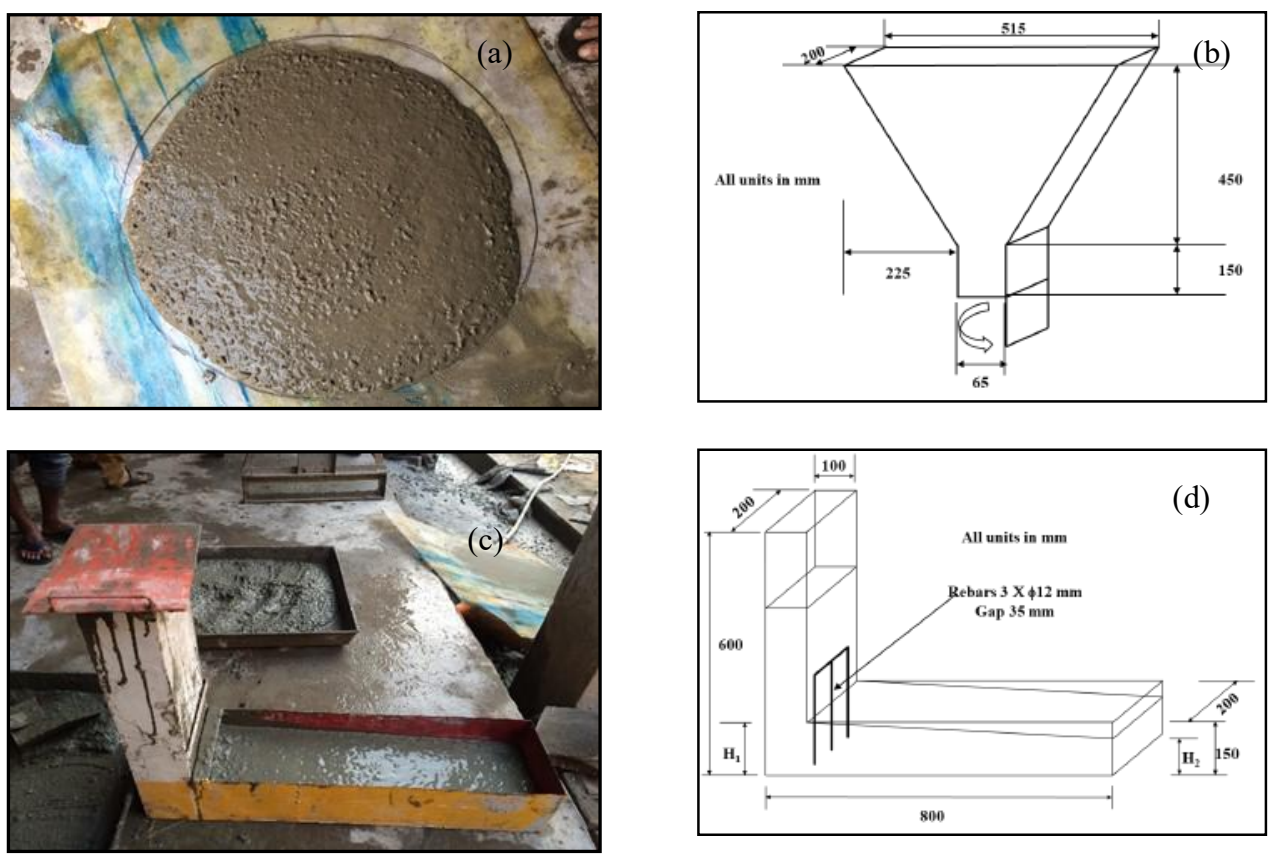

Figure 2: Tests on fresh properties of SCC (a) Slump flow test (b) V funnel test (c) L box test (d) Standard dimension for L box

\subsubsection{Slump Flow Test}

The slump flow test for SCC is similar to the conventional slump value test established for normal concrete, but the only difference is, this concrete does not require any external energy to fill the slump cone. According to EFNARC, concrete with a slump flow range of $600 \mathrm{~mm}$ to $800 \mathrm{~mm}$ confirms self compaction ability. A non- 
absorbent board marked with a $700 \mathrm{~mm}$ diameter circle was used (Figure 2a). The slump cone was placed at the centre of this circle and filled with concrete without any temping. The top surface of the slump cone was levelled by using a trowel. The cone was removed vertically, and the concrete was allowed to spread. The final diameter of the spread concrete was recorded.

\subsubsection{Funnel Flow Test}

In the $\mathrm{V}$ funnel flow test, the time required to flow through the $\mathrm{V}$ funnel indicates the viscosity of concrete which is a measure of segregation resistance ability.Approximately 13 liters of concrete were prepared to perform this test. A V funnel with standard dimension (Figure 2b) is placed vertically on flat ground and the inner surface of the funnel was moistened. A bucket was placed beneath the funnel and the trap door was closed. The funnel was completely poured with concrete in such a way that there is no application of external energy. The top of the funnel was smoothed by a trowel and the door was opened within 10 seconds. The time required to complete the discharge of concrete through funnel was recorded as the flow value for 10 seconds retention $\left(\mathrm{T}_{10 \mathrm{~s}}\right)$. To determine the $\mathrm{T}_{5 \min }$ flow value, the funnel was filled again and waited for 5 minutes before opening the door. The time required to pass the concrete through the outlet of $\mathrm{V}$ funnel after 5 minutes retention period in the funnel was recorded.

\subsubsection{Box Test}

L shaped mold was used in the $\mathrm{L}$ box test (Figure $2 \mathrm{c}$ ), which consists of a vertical section and a horizontal section having a movable door in their connection point (Figure 2d). In the joining point of these two sections, there was some fixed reinforcing bar to create an obstruction in passing. The movable door was opened after filling the vertical section and waited for the concrete to pass through the obstacles to reach the other end of the horizontal section. The height of concrete at both ends of the horizontal section was measured as $\mathrm{H}_{1} \& \mathrm{H}_{2}$.

\subsection{Sample Preparation and Curing}

Total 84 cylindrical specimens with a dimension of $100 \mathrm{~mm}$ diameter and $200 \mathrm{~mm}$ height were cast with a mix ratio obtained from the trial used to fulfil the requirements of fresh state properties of self-compacted concrete. Proper curing was confirmed by keeping the specimen into a curing chamber for the ages of 3 days, 7 days, 28 days, and 90 days.

\subsection{Preheating, Heating and Cooling Conditions}

A preliminary drying process was carried out for at least two hours at a temperature of $105 \pm 2{ }^{\circ} \mathrm{C}$ in an electric oven before heating the samples to elevated temperature in the furnace. This preheating was done to reduce the internal moisture content of the specimen as loss of free water from concrete generally occurs at about $100^{\circ} \mathrm{C}$.

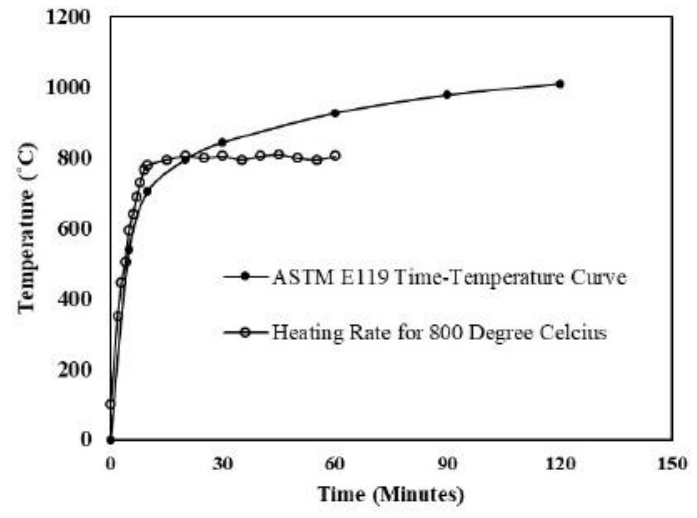

Figure 3: ASTM E119 standard time temperature curve Vs heating rate in the research

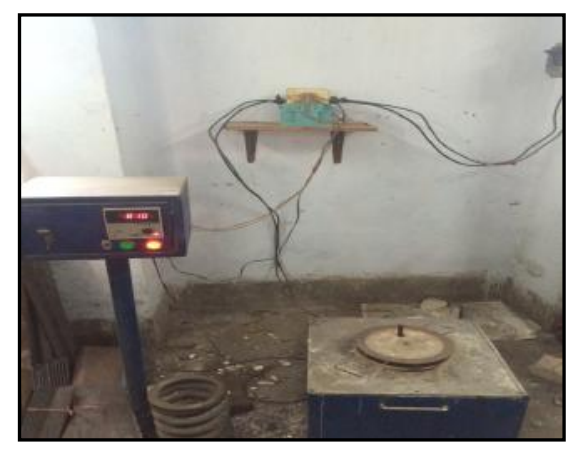

Figure 4: Electric Furnace with controlling system

A laboratory furnace with an internal dimension of $240 \mathrm{~mm}$ length, $240 \mathrm{~mm}$ width, and $275 \mathrm{~mm}$ depth is used for heating the specimens in different elevated temperatures $\left(150,300,450,600\right.$ and $\left.800^{\circ} \mathrm{C}\right)$. It has a control unit on its left side, as shown in Figure 4. The temperature of the furnace can be raised about $1200^{\circ} \mathrm{C}$. It has a cover on its top which has a diameter of $178 \mathrm{~mm}$. The heating process was performed according to the rate of heating of the ASTM E119 standard time-temperature curve. This curve represents the rate of change in temperature during a fire hazard. In this research up to 700-degree celsius, the heating rate has followed the ASTM E119 time-temperature curve for fire and a slight deviation from the fire curve was observed during an elevated 
temperature of $800^{\circ} \mathrm{C}$. The samples were heated for one hour at the desired maximum elevated temperature and cooled by two different cooling conditions. One is cooling naturally in the air for 24 hours, and another is force cooling into the water for 1 hour and kept in air for 23 hours.

\subsection{Tests on Mechanical Properties of SCC}

Tests on mechanical properties were performed after 24 hours from starting of cooling. The compressive strength, splitting tensile strength and elastic modulus of different elevated temperature and ambient temperature was determined using a digital compression testing machine.

\section{RESULTS}

\subsection{Properties of Self-Compacted Concrete}

The results obtained from several trials on fresh state characteristics of produced concrete by slump flow, Vshaped funnel flow and L box passing test are shown in Figure 5. The selected trial mix has a slump flow of about $657 \mathrm{~mm}$, which represents a good flowing capacity of concrete by its own weight through any congested section by eliminating frictional resistance. Table 3 represents the fresh state rheological properties of selected trial mix proportions.
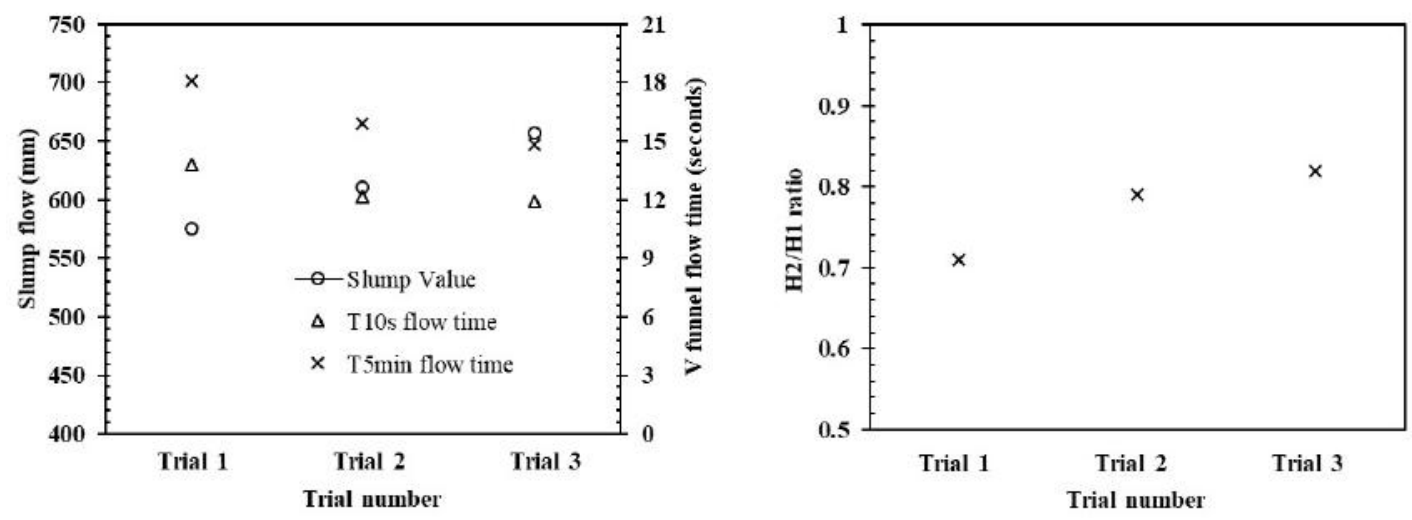

Figure 5: Rheological properties of SCC for different trial mix proportion

The time required to pass through the outlet of the V-shaped funnel after 10 seconds of placement of concrete gives a value of 11.93 seconds indicates moderate viscosity. European Federation of National Associations Representing for Concrete (EFNARC) recommended a range of about 8 to 12 seconds for possessing good flowing property where the limiting value of 8 seconds represents a concrete of very low viscosity. The variation between $\mathrm{T}_{5 \mathrm{~min}}$ flow time and $\mathrm{T}_{10 \mathrm{~s}}$ flow time is 2.92 seconds confirmed the segregation resistivity of the concrete.

Table 3: Fresh state rheological properties of selected trial mix proportion

\begin{tabular}{llr}
\hline Test name & Parameter & Result \\
\hline Slump flow test & Slump value $(\mathrm{mm})$ & 657 \\
& $\mathrm{~T}_{10 \mathrm{~s}}$ flow time $(\mathrm{sec})$ & 11.93 \\
V shaped funnel flow test & $\mathrm{T}_{5 \min }$ flow time $(\mathrm{sec})$ & 14.85 \\
L box passing test & $(\mathrm{H} 2 / \mathrm{H} 1)$ & 0.82 \\
\hline
\end{tabular}

\subsection{Compressive strength}

The compressive strength development of self-compacted concrete for different age of curing at air temperature is shown in Figure 6a. The maximum compressive strength attained after 90 days of curing was $27.0 \mathrm{MPa}$ at room temperature of $30^{\circ} \mathrm{C}$. Figure $6 \mathrm{~b}$ represents the compressive strength at different elevated temperatures. While heated to about $150^{\circ} \mathrm{C}$ has some increase in compressive strength and a continuous decrease in strength was observed from $300^{\circ} \mathrm{C}$ and thereafter heating. Above $110^{\circ} \mathrm{C}$, the chemically bound water from calcium silicate hydrate $(\mathrm{C}-\mathrm{S}-\mathrm{H})$ was started to release, and the intermolecular stress was increased due to thermal expansion of aggregate (Bingöl \& Gül, 2009; Seleem et al., 2011). When subjected to elevated temperature the strength of concrete structure started to decrease from $300^{\circ} \mathrm{C}$ due to the evaporation of chemically bound water and dehydration of $\mathrm{Ca}(\mathrm{OH})_{2}$ into free lime leading to the formation of micro-cracks inside the concrete (Demirel \& Keleştemur, 2010; Tufail et al., 2017). The strength of concrete is greatly affected due to the expansion of lime during the cooling period (Demirel \& Keleştemur, 2010). The strength may be increased if 
the adverse effect of lime can be minimized by adding some mineral additives. Mineral containing silicon dioxide from stone dust reacts with calcium hydroxide from cement to decrease the amount of lime from the system. As a result, an increment of strength was observed at $150^{\circ} \mathrm{C}$. This increment of strength also occurs when the free water from a concrete body was released, enhancing the frictional resistance between failure plane. Elevated temperature up to $300^{\circ} \mathrm{C}$ also enhance the hydration process of anhydrous cementitious component resulting in the proper bonding between aggregates and hence increase the strength (Fares et al., 2009; Rama Seshu \& Pratusha, 2013; Seleem et al., 2011).
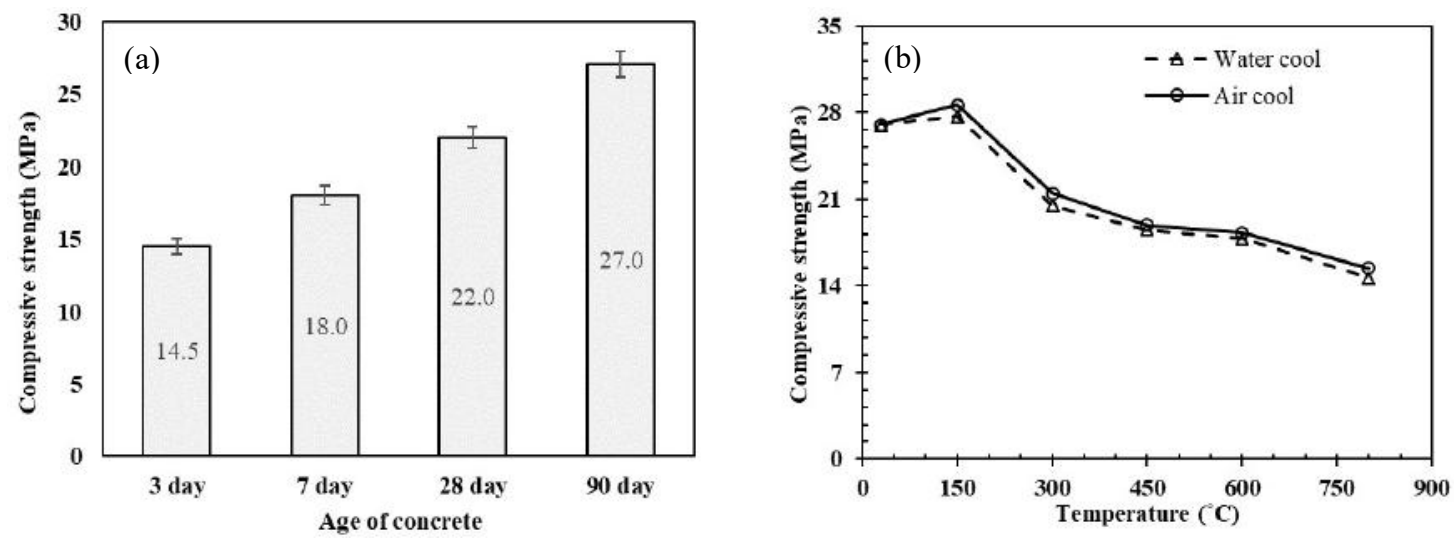

Figure 6: (a) Compressive strength against different age of curing (b) Compressive strength against different elevated temperatures and cooling conditions

In this test, it was observed that the concrete strength for water quenching \& cooling is slightly lower than that for air cooling after heated to elevated temperatures. After a fire accident, when extinguished by sudden quenching in water produce thermal shock due to the sudden drop of temperature within a few minutes (Botte \& Caspeele, 2017). As a result, natural cooling in air shows better result than sudden quenching in water after fire exposure. After $150^{\circ} \mathrm{C}$, in both cooling conditions, the strength of the concrete was decreased because of the expansion of lime that affects the volume occupied by other cementitious components (Heikal, 2000; Seleem et al., 2011). The concrete strength beyond $400^{\circ} \mathrm{C}$, decreased rapidly due to the dehydration of C-S-H (Heikal, 2000; Tufail et al., 2017). Effect of high temperature and cooling conditions on the residual strength of SCC can be observed from Figure 7.

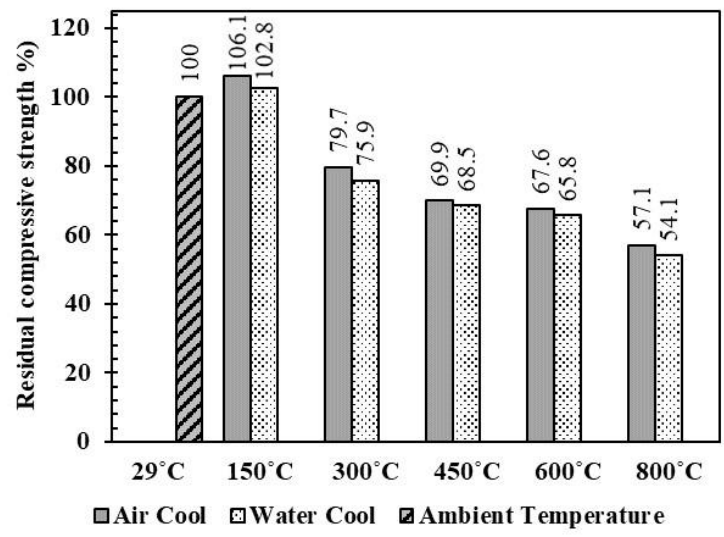

Figure 7: Comparison of residual compressive strength for different elevated temperatures and cooling conditions

The residual compressive strength was determined as a percentage of the strength of reference specimens $\left(29^{\circ} \mathrm{C}\right)$ which was available after considering the heating and cooling process. The minimum compressive strength was observed at $800^{\circ} \mathrm{C}$. The available compressive strength of SCC after heated to $800^{\circ} \mathrm{C}$ and cooled at air is $57.1 \%$, and when cooled at the water for 1 hour, the residual strength is $54.1 \%$ Compared to $30^{\circ} \mathrm{C}$.

\subsection{Tensile Strength}

The splitting tensile strength values from the tests on the specimens at ambient temperature and after heated to high temperature are represented in Figure 8. The tensile strength of concrete significantly decreased after 
elevated to high temperatures. The maximum tensile strength was noticed at natural temperature, and a gradual reduction was found on heating. The effect of cooling conditions was found similar to that of compressive strength. Suddenly cooling in water for one hour shows a significant reduction in tensile strength compared to cooling in the air for 24 hours. The residual tensile strength of SCC is shown in Figure 9. The residual tensile strength was above $92 \%$ for cooling in the air up to $300^{\circ} \mathrm{C}$, whereas sudden cooling in water shows an additional $6-7 \%$ drop in tensile strength. The tensile strength of self-compacted concrete was dropped to about $52 \%$ of its original capacity when heated to $800^{\circ} \mathrm{C}$ and cooled in water for one hour. For the same temperature, cooling through the air for 24 hours gives $15-16 \%$ more strength.

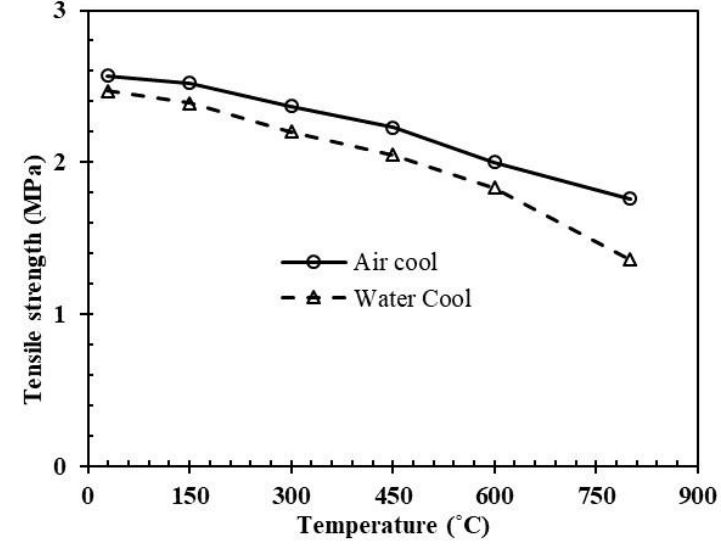

Figure 8: Tensile strength for different elevated temperatures and cooling conditions

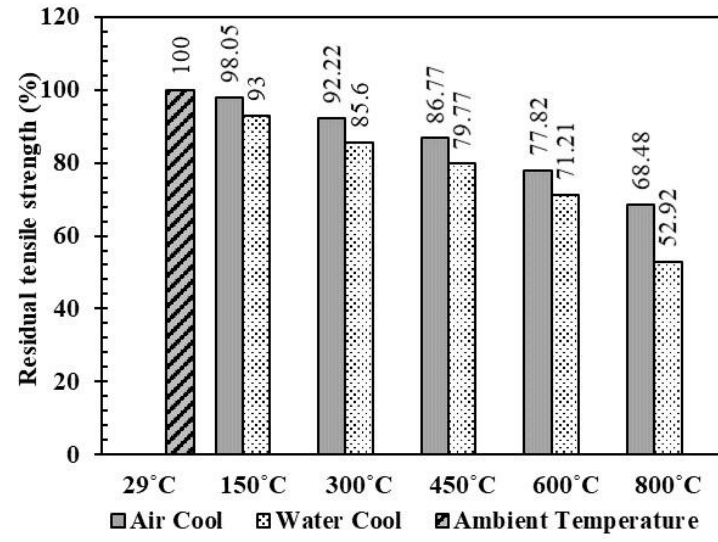

Figure 9: Comparison of residual tensile strength for different elevated temperatures and cooling conditions

\subsection{Modulus of Elasticity}

The modulus of elasticity of the specimens were determined according to ASTM C469. Tests on several specimens at elevated temperatures and cooling conditions were done to find out the elastic modulus of self compacted concrete and compared it to the values obtained for the specimens at room temperature to observe the change in elastic modulus at higher temperatures. The change in elasticity with temperature obtained from the investigation is reported in Figure 10.

The elastic modulus of self compacted concrete decreased at raised temperatures for both cooling conditions. Compared to sudden water cooling after heating, air cooling shows better results. The modulus of elasticity dropped from $23310 \mathrm{MPa}$ to $7055 \mathrm{MPa}$ with a maximum reduction of almost $70 \%$ (Figure 11) of reference stiffness of SCC $\left(30^{\circ} \mathrm{C}\right)$ when heated to $800^{\circ} \mathrm{C}$ and apply sudden cooling for 1 hour. About $30-40 \%$ drop in elasticity was noticed for the elevated temperature of within $300^{\circ} \mathrm{C}$, and after this temperature, a gradual decrease in elasticity was observed. The residual capacity of the stiffness for self-compacting concrete was dropped to $50 \%$ of its original capacity at the temperature ranges from $450-600^{\circ} \mathrm{C}$ (Figure 12).

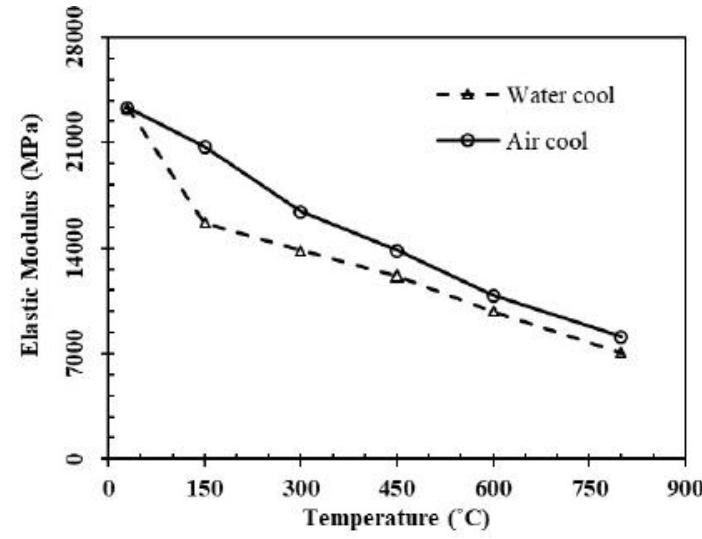

Figure 10: Elastic modulus for different elevated temperatures and cooling conditions

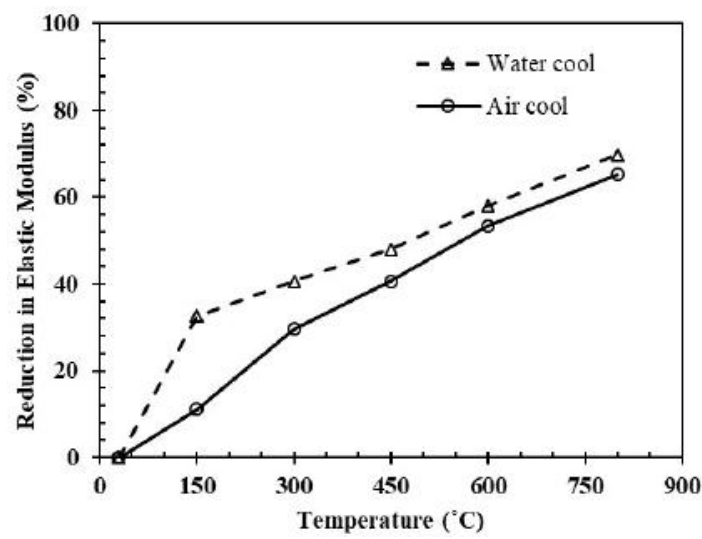

Figure 11: Reduction in Elastic modulus for different elevated temperatures and cooling conditions 


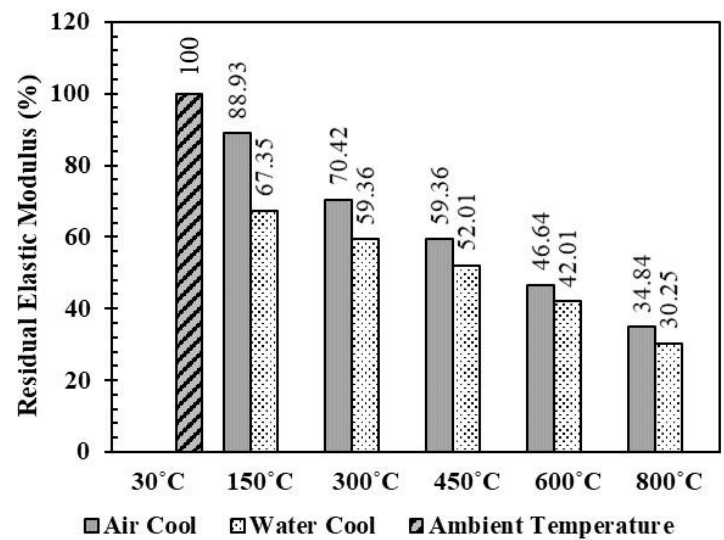

Figure 12: Comparison of residual elastic modulus for different elevated temperatures and cooling conditions

\section{CONCLUSIONS}

Self-compacting concrete is a special type of concrete that can solve the complexities arisen where external compaction can not be applied during the placement of concrete because of its good properties of self compactness. Evaluating the residual ability of the self-compacting concrete on its mechanical properties (compressive strength and tensile strength) at various exposures of high temperatures, the following conclusions have been found from experimental evidence.

- The compressive strength of SCC increased slightly at $150^{\circ} \mathrm{C}$ for both cooling conditions and started to decrease continuously on further heating from $300^{\circ} \mathrm{C}$.

- The residual strength was dropped significantly at $300^{\circ} \mathrm{C}$ by $20.26 \%$ for air cooling condition and gradually decreased above $300^{\circ} \mathrm{C}$.

- The tensile strength of SCC decreased continuously by incremental heating and diminution of $20 \%$ residual strength was observed at $450^{\circ} \mathrm{C}$.

- The modulus of elasticity for SCC made with locally available materials dropped to $50 \%$ of its original capacity when heated to a range of $450-600^{\circ} \mathrm{C}$.

- Cooling at room temperature for 24 hours in the air shows better results than sudden cooling in water for 1 hour.

\section{REFERENCES}

Anand, N., and Arulraj G. P., 2014. Effect of Grade of Concrete on the Performance of Self-Compacting Concrete Beams Subjected to Elevated Temperatures, Fire Technology, 50(5), 1269-1284.

Anand, N., Arulraj G., and Aravindhan C., 2014. Stress-Strain Behaviour of Normal Compacting and Self Compacting Concrete Under Elevated Temperatures, Journal of Structural Fire Engineering, 5(1), 6376.

Annerel, E., Taerwe L., and Vandevelde P., 2007. Assessment of temperature increase and residual strength of SCC after fire exposure, 5th International RILEM Symposium on Self-Compacting Concrete, 715.

Badogiannis, E. G., Sfikas I. P., Voukia D. V., Trezos K. G., and Tsivilis S. G., 2015. Durability of metakaolin Self-Compacting Concrete, Construction and Building Materials, 82, 133-141.

Bakhtiyari, S., Allahverdi A., Rais-Ghasemi M., Zarrabi B. A., and Parhizkar T., 2011. Self-compacting concrete containing different powders at elevated temperatures - Mechanical properties and changes in the phase composition of the paste, Thermochimica Acta, 514(1-2), 74-81.

Bartos, P. J. M., and Grauers M., 1999. Self-compacting concrete, Concrete, 33(4), 9-13.

Bingöl, A. F., and Gül, R., 2009. Effect of elevated temperatures and cooling regimes on normal strength concrete, Fire and Materials, 33(2), 79-88.

Botte, W., and Caspeele R., 2017. Post-cooling properties of concrete exposed to fire, Fire Safety Journal, 92 , $142-150$.

Calado, C., Camões A., Monteiro E., Helene P., and Barkokébas B., 2015. Durability Indicators Comparison for SCC and CC in Tropical Coastal Environments, Materials, 8(4), 1459-1481.

Castillo, C., 1990. Effect of transient high temperature on high-strength concrete, ACI Materials Journal, 47-53.

Chang, Y. F., Chen Y. H., Sheu M. S., and Yao G. C., 2006. Residual stress-strain relationship for concrete after exposure to high temperatures, Cement and Concrete Research, 36(10), 1999-2005.

Demirel, B., and Keleştemur O., 2010. Effect of elevated temperature on the mechanical properties of concrete produced with finely ground pumice and silica fume, Fire Safety Journal, 45(6-8), 385-391. 
Ding, Y., You Z., and Jalali S, 2011. The composite effect of steel fibres and stirrups on the shear behaviour of beams using self-consolidating concrete, Engineering Structures, 33(1), 107-117.

Ding, Y., You Z., and Jalali S., 2010. Hybrid fiber influence on strength and toughness of RC beams, Composite Structures, 92(9), 2083-2089.

Fares, H., Noumowe A., and Remond S., 2009. Self-consolidating concrete subjected to high temperature, Cement and Concrete Research, 39(12), 1230-1238.

Fares, H., Remond S., Noumowe A., and Cousture A., 2010. High temperature behaviour of self-consolidating concrete, Cement and Concrete Research, 40(3), 488-496.

Heikal, M., 2000. Effect of temperature on the physico-mechanical and mineralogical properties of Homra pozzolanic cement pastes, Cement and Concrete Research, 30(11), 1835-1839.

Heikal, M., Zohdy K. M., and Abdelkreem M., 2013. Mechanical, microstructure and rheological characteristics of high performance self-compacting cement pastes and concrete containing ground clay bricks, Construction and Building Materials, 38, 101-109.

Kanadasan, J., Fauzi A., Razak H., Selliah P., Subramaniam V., and Yusoff S., 2015. Feasibility Studies of Palm Oil Mill Waste Aggregates for the Construction Industry, Materials, 8(9), 6508-6530.

Lenka, S., and Panda K. C., 2017. Effect of metakaolin on the properties of conventional and self compacting concrete, Advances in Concrete Construction, 5(1), 31-48.

Mathew, G., and Paul M. M., 2012. Mix design methodology for laterized self compacting concrete and its behaviour at elevated temperature, Construction and Building Materials, 36, 104-109.

Noumowé, A., Carré H., Daoud A., and Toutanji H., 2006. High-Strength Self-Compacting Concrete Exposed to Fire Test, Journal of Materials in Civil Engineering, 18(6), 754-758.

Okamura, H., and Ouchi M., 2003. Self-Compacting Concrete, Journal of Advanced Concrete Technology, 1(1), $5-15$.

Pathak, N., and Siddique R., 2012. Properties of self-compacting-concrete containing fly ash subjected to elevated temperatures, Construction and Building Materials, 30, 274-280.

Persson, B., 2004. Fire resistance of self-compacting concrete, SCC, Materials and Structures, 37(9), $575-584$.

Phan, L. T., and Carino N. J., 1998. Review of Mechanical Properties of HSC at Elevated Temperature, Journal of Materials in Civil Engineering, 10(1), 58-65.

Rama Seshu, D., and Pratusha A., 2013. Study on compressive strength behaviour of normal concrete and selfcompacting concrete subjected to elevated temperatures, Magazine of Concrete Research, 65(7), 415421.

Rukavina, M. J., Bjegovic D., and Gabrijel I., 2015. Mechanical Properties of Self-Compacting Concrete with Different Mineral Aditives After High Temperature Exposure, Journal of Structural Fire Engineering, 6(3), 177-184.

Salhi, M., Ghrici M., Li A., and Bilir T., 2017. Effect of curing treatments on the material properties of hardened self-compacting concrete, Advances in Concrete Construction, 5(4), 359-375.

Seleem, H. E. H., Rashad A. M., and Elsokary T., 2011. Effect of elevated temperature on physico-mechanical properties of blended cement concrete, Construction and Building Materials, 25(2), 1009-1017.

Tao, J., Yuan Y., and Taerwe L., 2010. Compressive Strength of Self-Compacting Concrete during HighTemperature Exposure, Journal of Materials in Civil Engineering, 22(10), 1005-1011.

Tufail, M., Shahzada K., Gencturk B., and Wei J., 2017. Effect of Elevated Temperature on Mechanical Properties of Limestone, Quartzite and Granite Concrete, International Journal of Concrete Structures and Materials, 11(1), 17-28.

Vasusmitha, R., and Rao D. P. S., 2012. Effect Of Elevated Temperature On Mechanical Properties Of High Strength Self Compacting Concrete, International Journal of Engineering Research \& Technology, $1(8)$.

(C) 2020 The Authors. Journal of Engineering Science published by Faculty of Civil Engineering, Khulna University of Engineering \& Technology. This is an open access article under the terms of the Creative Commons AttributionNonCommercial-NoDerivatives License, which permits use and distribution in any medium, provided the original work is properly cited, the use is non-commercial and no modifications or adaptations are made. 